\title{
Three Species of Lamellodiscus (Monogenea: Diplectanidae) from the Gills of the Japanese Black Sea Bream, Acanthopagrus schlegeli (BLEEKER)
}

\author{
Kazuo Ogawa* and Syuzo Egusa* \\ (Received January 6, 1978)
}

\begin{abstract}
Descriptions and identifications are made of three species of Lamellodiscus parasitizing the gills of the Japanese black sea bream, Acanthopagrus schlegeli (BLEEKER) cultured at farms in Hiroshima and Shizuoka Prefs., Japan. Among the three species, one is identified as L. spari ZHuxov, 1970 and the other two, L. takitai n.sp. and L. japonicus n.sp. L. takitai n.sp. somewhat resembles $L$. verberis EUZET et OLIVER, 1967 in the shape of the copulatory organ, but may be distinguished from the latter species in the shape of the vagina. L. japonicus n.sp. may differ from all other Lamellodiscus species in the shape of the copulatory organ.

Morphologically, the following characteristics should be noted. 1) The vas deferens turns round the left intestine. This may possibly be common to all Lamellodiscus species, although it has been described as not turning round the intestine in all previous papers. 2) The prostatic reservoir is longitudinally bipartite. 3) In $L$. spari, the vagina opens on the right side of the body, which seems to be an exceptional case in the genus.
\end{abstract}

During the parasitological investigations of the Japanese black sea bream, Acanthopagrus schlegeli (Japanese common name: "Kurodai"), three species of Lamellodiscus were found parasitic on the gills. One of them was identified as $L$. spari ZuUkov, $1970^{11}$ and the others were found to be new species; the specific names, L. takitai n.sp. and $L$. japonicus n.sp. are given for them. Descriptions of the chitinous parts as well as the general structures are made of these species in this paper.

There was only one record of Lamellodiscus in Japan by YAMAGUTI ${ }^{2)}$ who reported $L$. pagrosomi MURRAY, $1931^{31}$ from the gills of Pagrus major (Japanese common name: "Madai"; syn: Pagrosomus unicolor). This is the second report of Lamellodiscus species in Japan.

\section{Materials and Methods}

The Japanese black sea bream, Acanthopagrus schlegeli (BLEEKER), from which Lamellodiscus specimens were collected, were obtained from farms in Hiroshima and Shizuoka Prefs., Japan. They were $13.3-20.9 \mathrm{~cm}$ in total length and 30 $140 \mathrm{~g}$ in body weight. The permanent preparations of the parasites for observation were made by the methods described in a previous paper."
Drawings were made with the aid of a camera lucida.

\section{Descriptions of the Species}

(I) Lamellodiscus takitai n.sp. (Figs. 1-4)

Host: Acanthopagrus schlegeli (BLEEKER).

Habitat: Gill filament.

Localities and dates: Hiroshima Pref., Aug. 1976 and Feb. 1977; Shizuoka Pref., Oct. and Nov. 1976.

Specimens: The holotype and some paratypes are deposited in the Meguro Parasitological Museum, M.P.M. Coll. No. 19243 and the other paratypes in the authors' collection.

Description: (a) Chitinous parts (specimens examined: 10). Chitinous structure of the opisthaptor consists of two pairs of anchors (ventral and dorsal), two lateral bars, a central bar, a pair of squamodiscs and seven pairs of marginal hooks. Both pairs of anchors lie on the lateral sides of the opisthaptor. The slender ventral anchor is 54 $67 \mu \mathrm{m}$ (mean $63 \mu \mathrm{m}$ ) long. Its internal and external processes are 8-12 $\mu \mathrm{m}$ and 6-10 $\mu \mathrm{m}$ long, respectively. The dorsal anchor is $47-55 \mu \mathrm{m}$ (mean $53 \mu \mathrm{m}$ ) long with the rudimentary external process. The central bar with its ends tapering and directing anteriorly, measures $55-63 \mu \mathrm{m}$

* Department of Fisheries, Faculty of Agriculture, the University of Tokyo, Tokyo, Japan (小川和夫・江草周 三: 東京大学歲学部水座学料). 


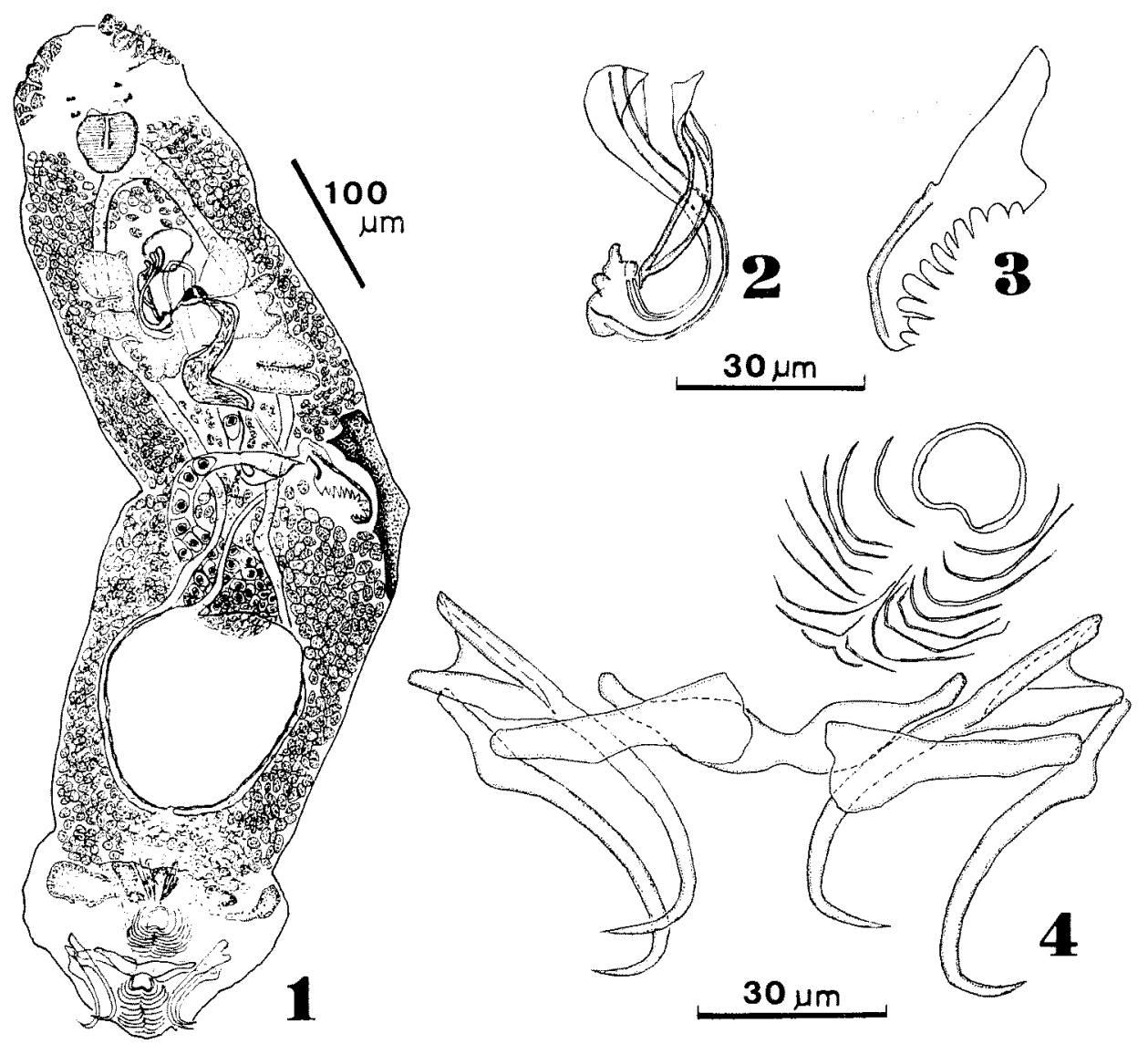

Figs. 1-4. Lamellodiscus takitai n.sp. 1: the whole worm of the holotype, ventral view. 2: copulatory organ of paratype. 3: vagina of paratype. 4: squamodisc and anchor complex of paratype.

(mean $58 \mu \mathrm{m}$ ) in length. It is constricted in the middle where it is $5-6 \mu \mathrm{m}$ in width. The lateral bar (38-44 $\mu \mathrm{m}$ long) is almost straight and widened distally. Two squamodiscs $(35-50 \mu \mathrm{m}$ in diameter) are situated on the ventral and dorsal surfaces of the opisthaptor, each squamodisc consisting of ten pairs of chitinous lamellae. The anteriormost pair is thick and forms a complete circle, while the remainder are thinner and the ends of each pair do not meet. Seven pairs of marginal hooks, 9-11 $\mu \mathrm{m}$ in length, are typical in shape in the genus. One pair of them (pair I) lies in the center of the opisthaptor, and the remaining six pairs at its margin.

The curved cirrus (41-50 $\mu \mathrm{m}$, mean $46 \mu \mathrm{m}$ long) is provided with a thin and blade-shaped attachment at the distal part, and accompanied by an accessory (38-43 $\mu \mathrm{m}$, mean $41 \mu \mathrm{m}$ long), which originates at the cirrus base. The accessory is hollow in the middle and pointed distally. The vagina (45-63 $\mu \mathrm{m}$ long) is very characteristic in shape; its opening forms an arched row of lightly chitinized spines.

(b) General structure (specimens examined: 10). This species is largest among the three species described in this paper, being $544-880 \mu \mathrm{m}$ long by $147-237 \mu \mathrm{m}$ wide. The body is elongated and flattened dorso-ventrally. The opisthaptor is 71$102 \mu \mathrm{m}$ long by $132-178 \mu \mathrm{m}$ wide. Three pairs of head organs are well developed. Four eye spots are present in front of the pharynx. The mouth directly leads into the pharynx (36-48 $\mu \mathrm{m}$ long by $38-53 \mu \mathrm{m}$ wide). The oesophagus is short. The bifurcating intestines run on both sides of the body, terminating blindly at the posterior end of the testis. On the way, they strongly wind inward at the sites of both the oviduct and the vas deferens turning round them. 
The irregularly rounded testis (113-222 $\mu \mathrm{m}$ long by $80-196 \mu \mathrm{m}$ wide) is very large, occupying a large part of the hindbody. The vas deferens emerges from its right anterior edge. Passing the ventral side of the ovary, it ascends obliquely to the left and turns round the left intestine from the dorsal side. Then, it takes its course obliquely to the right, and after forming the curved vesicula seminalis (10-14 $\mu \mathrm{m}$ in width) by its mere dilatation, it leads into the cirrus base. The prostate gland is distributed widely from the level of the genital pore to that of the posterior end of the vesicula seminalis. The single prostatic reservoir (15-19 $\mu \mathrm{m}$ long by $6-17 \mu \mathrm{m}$ wide) is located near the cirrus base and is longitudinally bipartite; namely it is divided into the granular region and the transparent one. The genital opening lies on the median line at the level of the distal end of the copulatory organ.
The ovary, curved and flask-shaped, is located in the middle of the body. It originates dorsally to the testis, and overlapps with the latter. Turning round the right intestine dorsally, the oviduct is united on the median line with the vaginal duct to form the receptaculum seminis (25-37 $\mu \mathrm{m}$ long by $11-19 \mu \mathrm{m}$ wide). The vagina opens on the left of the body. Outside of it exists a well developed gland which seems to play as a sticky gland at copulation. The oviduct, after forming the receptaculum seminis, proceeds backward from the latter, and soon changes its course forward. Receiving the MeHLIS' gland to form the ootype, it leads into the genital opening. The vitellaria are profuse, distributed from the level of the pharynx to the end of the body proper. The cement gland starts from the basal part of the opisthaptor.

Discussion: This species somewhat resembles L. verberis EUzET et OLIVER, 1967 in the shape of
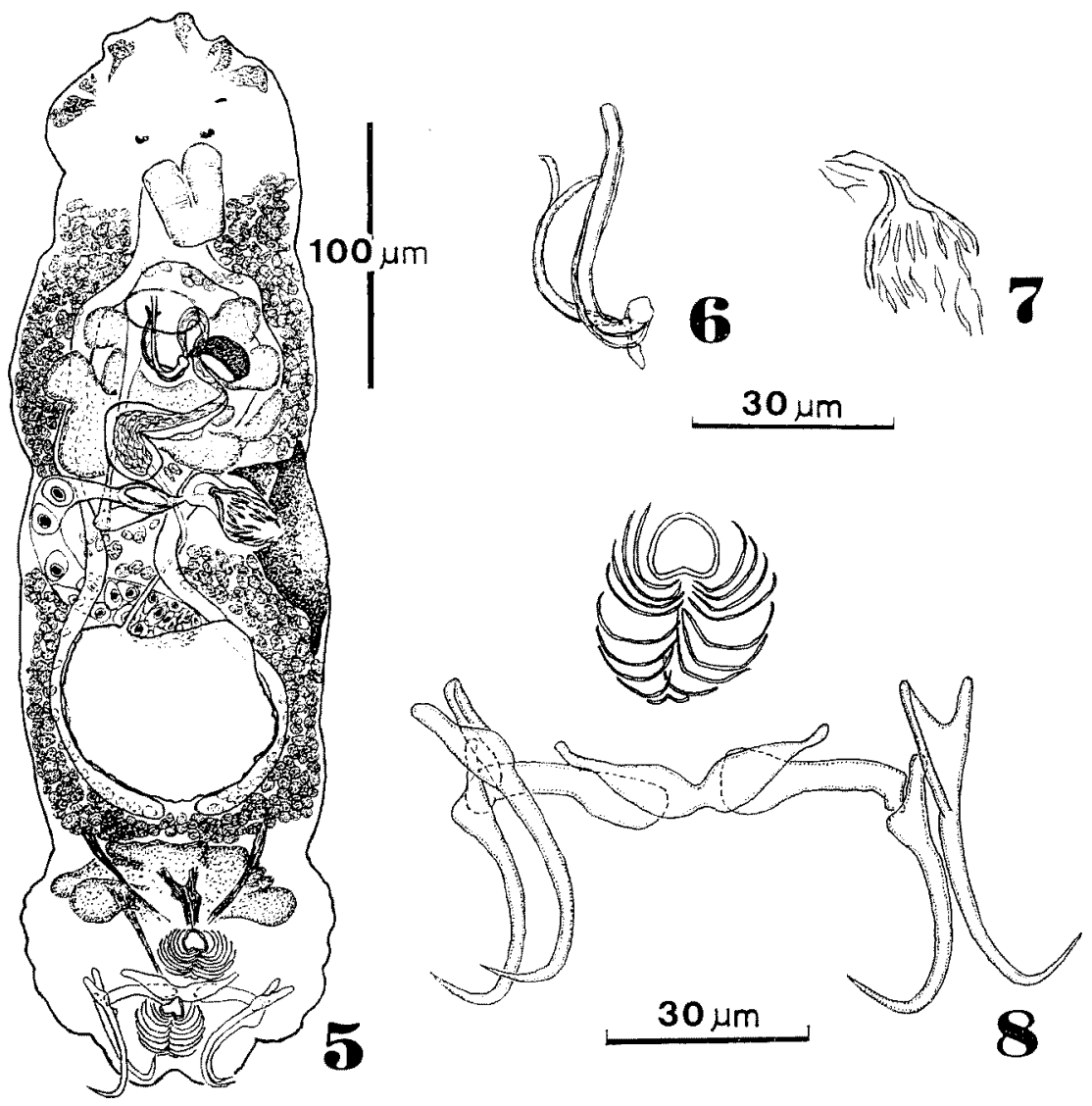

Figs. 5-8. Lamellodiscus japonicus n.sp. 5: the whole worm of the holotype, ventral view. 6: copulatory organ of paratype. 7: vagina of paratype. 8: squamodisc and anchor complex of paratype. 
the copulatory organ (Fig. 13, p. 422 of their paper $^{5 /}$ ), but can be discriminated by the shape of the vagina.

It should be noted that the vas deferens of this species as well as the other two species described in this paper does turn round the left intestine. Internal morphology of Lamellodiscus species has been studied in detail by several authors ${ }^{2,6,7)}$. However, in all the previously reported species of the genus, the vas deferens was described as not turning round the intestine.

The specific name is dedicated to our co-worker, the late Mr. S. TAKITA, Department of Fisheries, Faculty of Agriculture, the University of Tokyo.

\section{(2) Lamellodiscus japonicus n.sp. (Figs. 5-8)}

Host: Acanthopagrus schlegeli (BLEEKER).

Habitat: Gill filament.

Locality and date: Hiroshima Pref., Aug. 1976.

Specimens: The holotype and some paratypes are deposited in the Meguro Parasitological Museum, M.P.M. Coll. No. 19244, and the other paratypes in the authors' collection.

Description: (a) Chitinous parts (specimens examined: 10). Chitinous apparatus of the opisthaptor of this species is quite similar in shape to that of L. takitai, but considerably smaller in the measurements. The ventral anchor is $46-54 \mu \mathrm{m}$ (mean $50 \mu \mathrm{m}$ ) long. Its internal and external processes are $6-8 \mu \mathrm{m}$ and $6-10 \mu \mathrm{m}$ long, respectively. The dorsal anchor is $38-47 \mu \mathrm{m}$ (mean $42 \mu \mathrm{m}$ ) long. The central bar is $41-47 \mu \mathrm{m}$ (mean $44 \mu \mathrm{m})$ long with its width in the middle being 3$4 \mu \mathrm{m}$. The lateral bar is $28-34 \mu \mathrm{m}$ long. Each squamodisc, $24-32 \mu \mathrm{m}$ in diameter, consists of ten lamellae. The marginal hooks are the same in shape and size (8-10 $\mu \mathrm{m}$ long).

The copulatory organ consists of the cirrus and its accessory. The former, which is curved basally, is a simple tube, measuring $34-39 \mu \mathrm{m}$ (mean $36 \mu \mathrm{m})$ long by $3 \mu \mathrm{m}$ wide. The latter (26-32 $\mu \mathrm{m}$ long), which is also curved basally, is tubular and diverged distally. The lightly chitinized vagina (26-35 $\mu \mathrm{m}$ long by $15-22 \mu \mathrm{m}$ wide) is funnel- and flame-shaped at its opening.

(b) General structure (specimens examined: 10). The body is smallest among the three species; $307-516 \mu \mathrm{m}$ long by $90-139 \mu \mathrm{m}$ wide. The opisthaptor is $52-83 \mu \mathrm{m}$ long by $92-124 \mu \mathrm{m}$ wide.

The general structure completely coincides with that of $L$. takitai. The measurements of various body parts are as follows: the pharynx, $27-41 \mu \mathrm{m}$ long by $25-38 \mu \mathrm{m}$ wide; the testis, $53-$
$125 \mu \mathrm{m}$ long by $52-104 \mu \mathrm{m}$ wide; the curved vesicula seminalis, $12-17 \mu \mathrm{m}$ wide; the ellipsoidal prostatic reservoir, which is longitudinally bipartite, $19-23 \mu \mathrm{m}$ long by $13-17 \mu \mathrm{m}$ wide; the flask-shaped ovary, 54-106 $\mu \mathrm{m}$ long by $17-30 \mu \mathrm{m}$ wide; the ellipsoidal receptaculum seminis, 12$22 \mu \mathrm{m}$ long by $6-15 \mu \mathrm{m}$ wide. Outside of the vagina there exists a well developed gland similar to that of L. takitai.

Discussion: This species is distinguished from all other species of Lamellodiscus by the shape of the copulatory organ; the simple cirrus tube is accompanied by the diverged accessory.

\section{(3) Lamellodiscus spari Zuukov, 1970 (Figs. 9-} 12)

Host: Acanthopagrus schlegeli (BLEEKER).

Habitat: Gill filament.

Localities and dates: Hiroshima Pref., Aug. 1976; Shizuoka Pref., Oct. and Nov. 1976.

Specimens: Deposited in the Meguro Parasitological Museum, M.P.M. Coll. No. 19245 and in the authors' collection.

Description: (a) Chitinous parts (specimens examined: 10). Chitinous armament of the opisthaptor of this species is characterized by the large squamodiscs and the short point lengths of both the vental and dorsal anchors. The ventral anchor is $42-51 \mu \mathrm{m}$ (mean $46 \mu \mathrm{m}$ ) long. Its internal and external processes are $12-15 \mu \mathrm{m}$ and 4-8 $\mu \mathrm{m}$ long, respectively. The dorsal anchor is $36-45 \mu \mathrm{m}$ (mean $40 \mu \mathrm{m}$ ) long. The central bar is $71-84 \mu \mathrm{m}$ (mean $79 \mu \mathrm{m}$ ) long with its ends directing almost transversely. The lateral bar is $28-34 \mu \mathrm{m}$ long. The squamodisc, $70-111 \mu \mathrm{m}$ in diameter, is made up of nine to ten pairs of lamellae. The marginal hooks are of usual shape, measuring 9-10 $\mu \mathrm{m}$ long.

The vagina consists of a chitinous opening and a very lightly chitinized duct. The cirrus is a simple tube and curved strongly so as to form the letter $\mathrm{U}$, tapering distally. It measures $19-20 \mu \mathrm{m}$ in length in a straight line and $9-10 \mu \mathrm{m}$ in the basal width. The cirrus accessory, 25-27 $\mu \mathrm{m}$ long, is tubular and pointed distally. It is curved spirally to form the letter $S$, so that its terminal faces the cirrus tip.

(b) General structure (specimens examined: 10). The body is $425-580 \mu \mathrm{m}$ long and widest at the ovarin region, measuring $108-136 \mu \mathrm{m}$ wide. The opisthaptor is $152-189 \mu \mathrm{m}$ wide, but its length cannot be confirmed, because it is not well marked off from the body proper. The internal mor- 


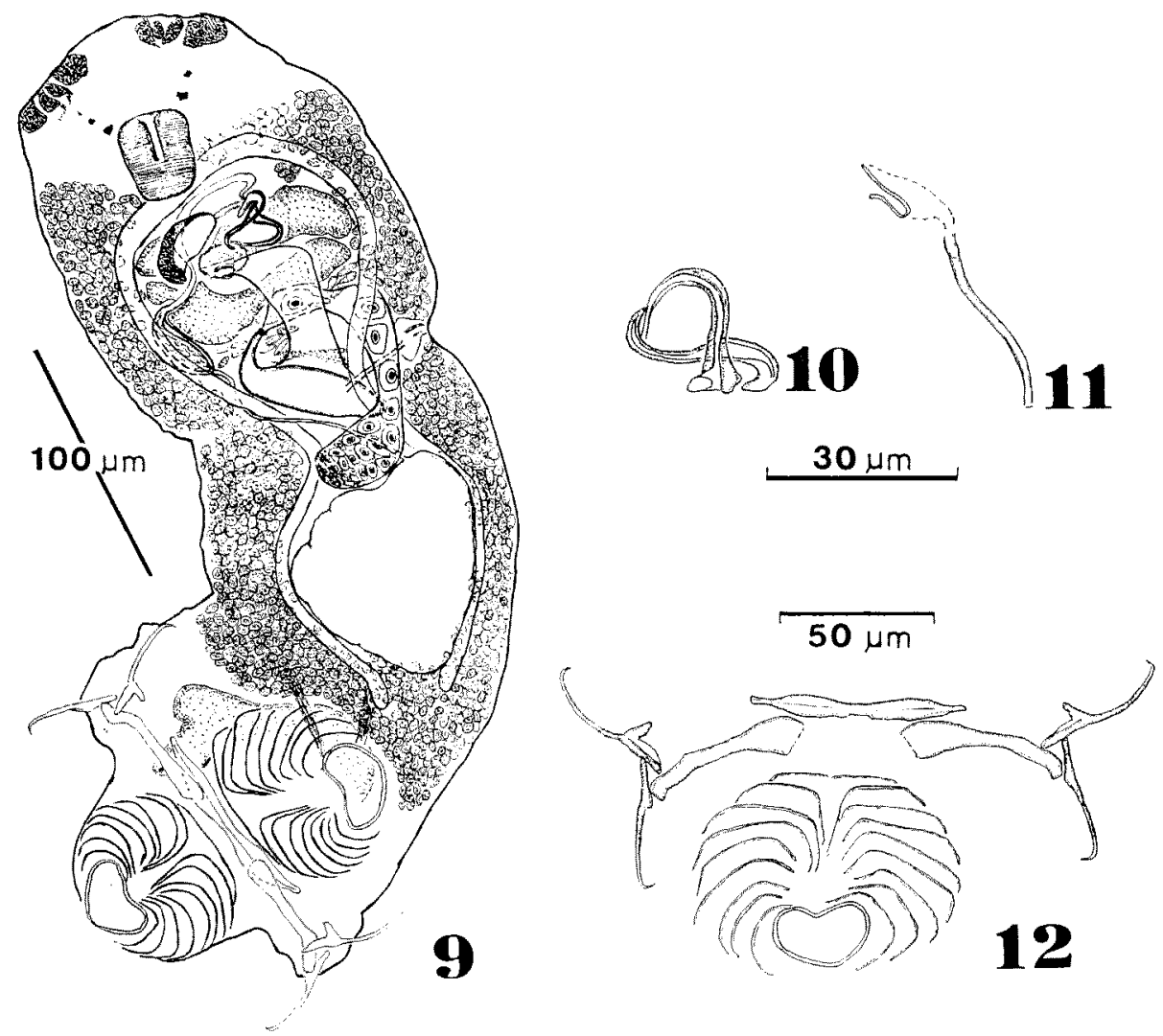

Figs. 9-12. Lamellodiscus spari ZHuKov, 1970. 9: whole worm, dorsal view. 10: copulatory organ. 11: vagina. 12: squamodisc and anchor complex.

phology coincides with those of the above two species except the following. The vagina opens on the right lateral margin of the body, and the vaginal duct leads into the posterior part of the receptaculum seminis which is provided with a sphincter at the site of the connection with the oviduct. The vaginal gland as observed in the above two species is lacking. The oviduct arises anteriorly from the receptaculum seminis, while the oviducts of $L$. takitai and $L$. japonicus at first start backward from the receptaculum seminis and soon turn forward.

The description of the other structures is as follows. The pharynx is $36-48 \mu \mathrm{m}$ long by 38 $53 \mu \mathrm{m}$ wide. The large testis is $88-122 \mu \mathrm{m}$ long by $62-93 \mu \mathrm{m}$ wide. The ovary is $80-125 \mu \mathrm{m}$ long by $22-32 \mu \mathrm{m}$ wide. The vesicula seminalis (7$14 \mu \mathrm{m}$ wide) is curved and sometimes so poorly dilated that it is not recognized as a distinctive vesicle. The receptaculum seminis, $29-46 \mu \mathrm{m}$ by $27-28 \mu \mathrm{m}$ in size, is large and ellipsoidal, ex- tending posteriorly to the right. The prostatic reservoir is logitudinally bipartite and large, being $15-29 \mu \mathrm{m}$ by $6-17 \mu \mathrm{m}$ in size.

Discussion: ZHukov ${ }^{1 /}$ reported $L$. spari as a new species from the gills of "Sparus macrocephalus czerskii BERG" at the Posjet Bay, the Sea of Japan. Although the shapes of the chitinous parts are much the same between the present specimens and those of ZHuKov, the former are considerably smaller in their measurements. For example, the total length of the ventral anchor of the present specimens ranges $42-51 \mu \mathrm{m}$ (mean $46 \mu \mathrm{m}$ ) long, while that of his specimens $53-55 \mu \mathrm{m}$ long. The present specimens were collected from the hosts at the water temperatures $22-24^{\circ} \mathrm{C}$, while his specimens were probably obtained in colder waters. Generally, the chitinous parts are known to become longer in colder circumstances. Taking this into consideration, the differences in the measurements may become insignificant, and lie within the limits of specific variations. 
It is sufficient to note that the vagina opens on the right side of the body, which seems to be an exceptional case in the genus as well as in $L$. corallinus PAPERNA, $1965^{81}$ and L. minousi GUPTA et Khullar, $1967^{9 !}$.

\section{Acknowledgements}

The present authors wish to express their sincere thanks to Dr. Sh. Kamegai, Meguro Parasitological Museum, Tokyo, for his helpful instructions. Thanks are also due to Mr. K. MasumurA, Hiroshima Prefectural Fisheries Experimental Station, Ondo, Hiroshima Pref. and to Mr. M. SORIMACHI, Labolatory of Fisheries, Faculty of Agriculture, the University of Tokyo, Maisaka, Shizuoka Pref. for supplying them the fish.

\section{References}

1) E. V. Zhukov: Parazitologiya, 4, 321-326 (1970).

2) S. Yamaguti: Japan. J. Zool., 8, 15-74 (1938).

3) F. V. Murray: Parasit., 23, 492-506 (1931).

4) K. Ogawa and S. Egusa: Bull. Japan. Soc. Sci. Fish., 44, 305-312 (1978).

5) L. Euzer and G. Oliver: Annls. Parasit. hum. comp., 42, 407-425 (1967).

6) S. YAMAGUTI: Acta Med. Okayama, 8, 203-256 (1953).

7) L. Euzet and G. Oliver: Annls. Parasit. hum. comp., 41, 573-598 (1966).

8) I. Paperna: Bull. Sea Fish. Res. Stn. Israel, 39, 17-26 (1965).

9) N. K. Gupta and M. Khullar: Res. Bull. Panjab Univ., New Ser., 18, 429-431 (1967). 